\section{E-LOGOS}

ELECTRONIC JOURNAL FOR PHILOSOPHY ISSN 1211-0442

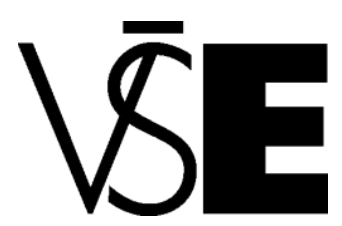

University of Economics

Prague

\title{
Etika Francise Hutchesona
}

\author{
Miroslav Vacura
}

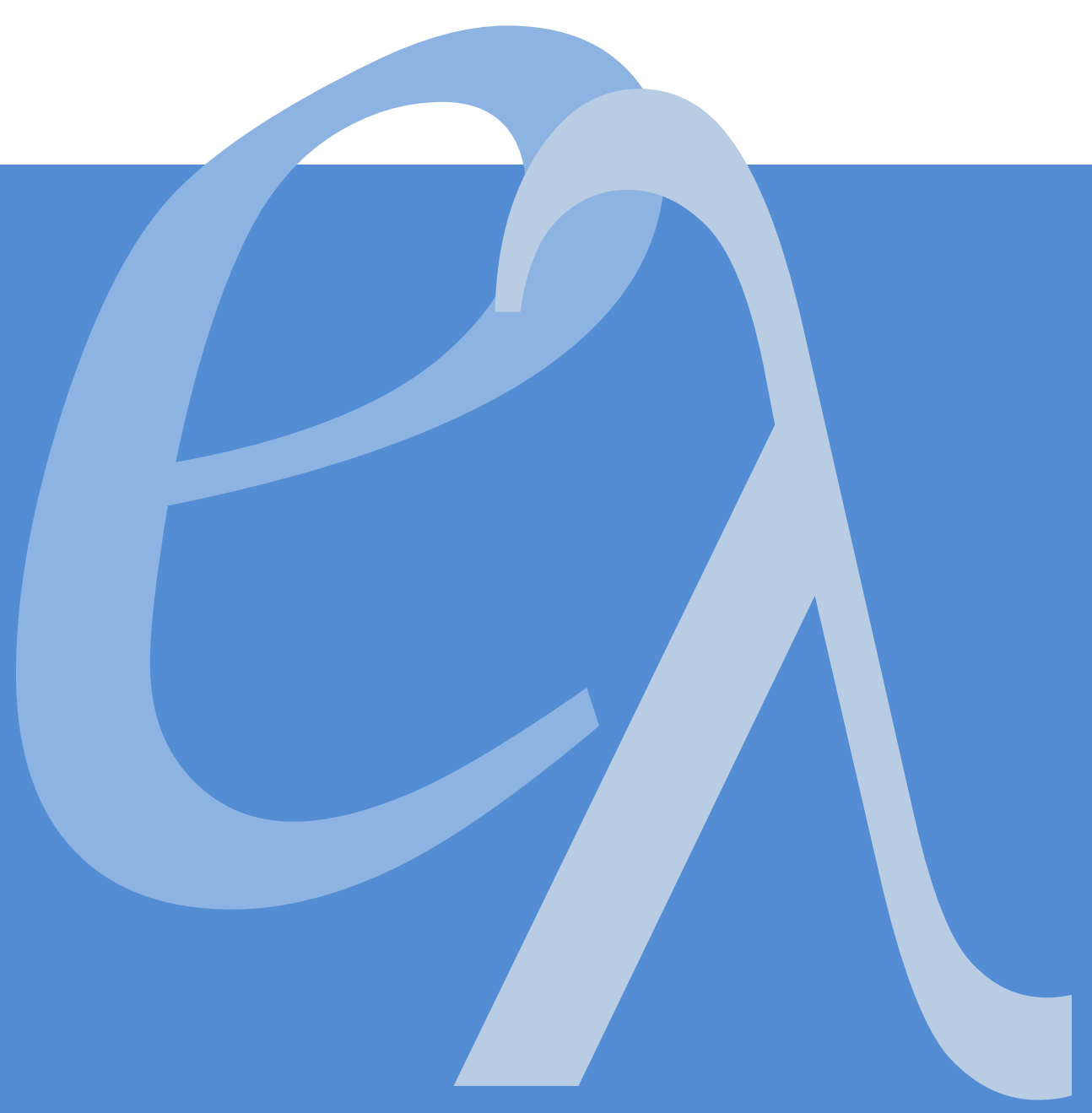




\begin{abstract}
The paper presents ethical theory of Francis Hutcheson, one of the most important sentimentalist philosphers. The main focus is on his Essay on the Nature and Conduct of the Passions and paper presents it's main arguments toghether with some critical remarks.
\end{abstract}

\title{
Abstrakt
}

Článek se zabývá etickou teorií Francise Hutchesona, jednoho z nejvýznamnějších představitelů sentimentalistické etické filosofie. Hlavní důraz je kladen na spis Essay on the Nature and Conduct of the Passions z něhož jsou představeny nejdůležitější argumenty spolu s kritickými poznámkami. 
Francis Hutcheson je autorem řady spisů zabývajících se etickou tematikou. Tématem prvního jeho významného spisu An Inquiry into the Original of our Ideas of Beauty and Virtue (1725) (dále jen Inquiry) je sice primárně estetika a empirická teorie krásna, nicméně tento spis obsahuje druhou část nazvanou An Inquiry Concerning the Original of Our Ideas of Virtue or Moral Good, která se zabývá už převážně etickou tematikou. Druhým a pravděpodobně nejvýznamnějším Hutchesonovým spisem je An Essay on the Nature and Conduct of the Passions, with Illustrations upon the Moral Sense (1728) (dále jen Essay), rozdělená do dvou částí: první je samotná Essay, ve které je vyloženo jádro jeho etické koncepce, druhou jsou pak Illustrations, které jsou převážně výsledkem jeho polemiky s Gilbertem Burnetem v London Journal. Dva zatím zmíněné spisy jsou označovány za rané. Na sklonku života Hutcheson ještě publikuje dvě další etická pojednání, řazená do jeho pozdního období: Introduction to Moral Philosophy (1747) a The System of Moral Philosophy (1755); tyto texty však nejsou považovány za, ve srovnání s předcházejícími, významné. $V$ tomto textu budeme při výkladu základních prvků Hutchesonova etického systému vycházet z jeho Essaye.

O hlavním cíli Hutchesonovy etiky si lze udělat obrázek na základě málo známého článku, který Hutcheson anonymně zveřejnil v London Journal před uveřejněním svých hlavních spisů a který přináší některé jeho kritické úvahy na témata týkající se etických koncepcí tehdejších nejvýznamnějších britských morálních myslitelů. ${ }^{1}$ Ač zde nejsou jmenováni, jeho zájem se soustředí zejména na díla $S$. Clarka $^{2}$ a W. Wollastona. ${ }^{3}$ Jedná se o teologicky orientované myslitele, jejichž etické teorie jsou ve své podstatě založeny na individuálním sobectví a systému odměn a trestů v budoucnosti, v konečném důsledku religiózně fundovaných. Podobně egoistickou, ovšem ve své podstatě sekulární, etiku vypracovává také T. Hobbes, který identifikuje dobro s prŕijemnem a zlo s nepř́ijemnem. J. Locke na stejných základech odmítá možnost zákona, který by nebyl zaštítěn hrozbou trestu za jeho nedodržení, což chápe v podstatě, moderními slovy, jako analyticky zřejmé.

Tyto etické koncepce, se kterými se Hutcheson potýkal, ve své době přehledně shrnuje Frankena:4

1. Egoismus Hobbese či Mandevilleho.

2. Teologický voluntarismus Locka a Berkeleyeho.

3. Racionalismus a intuicionismus Clarka a Wollastona.

4. Shaftesburyho etika.

\footnotetext{
${ }^{1}$ Aldridge, A. O. A Preview of Hutcheson's Ethics. In: Modern Language Notes, Vol. 61, No. 3 (Mar., 1946), pp. 153-161.

2 Clarke, S. A Demonstration of the Being and Attributes of God And Other Writings, E. Vailati (ed.), Cambridge: Cambridge University Press, 1998.

${ }^{3}$ Wollastone, W. The Religion of Nature Delineated. Printed by S. Palmer, 1725.

${ }^{4}$ Frankena, W. Hutchesons Moral Sense Theory. str. 357.
} 
Toto (vyjma 4) jsou koncepce, proti kterým se Hutcheson staví do opozice, ovšem opět na principiálně empiristických základech. Hutchesonovu argumentaci proti koncepcím 1 a 2 se pokusíme rekonstruovat v části tohoto textu věnované vyvrácení hédonismu. V protikladu $\mathrm{k}$ etické koncepci 2 odmítá závislost etiky na teologii a proti koncepci 3 argumentuje na epistemických a psychologických základech v duchu post-Lockovského empirismu. Část své argumentační strategie přebírá od Shaftesburyho, ovšem jeho postoje dále upřesňuje a systematizuje. ${ }^{5}$

Základní Hutchesonovou myšlenkou je, že to není rozum, ale smyslové afekce, které stojí v základu naší morálky. Rozum je zde ovšem chápán jako prostředek kalkulu strastí a slastí, pouze v tomto smyslu je na rozumu založena etika jeho výše zmiňovaných předchůdců. Dokladem je mimo jiné to, že ti, kteří jsou na rozumové úrovni nejzběhlejší v principech morálky, nejsou vždy nutně nejmorálnějšími lidmi.

Obecně Hutcheson odmítá jakýkoli etický systém, který by byl založen na principu individuálního zájmu. Například podle Pufendorfa lidské štěstí záleží na stavu společnosti, ve které člověk žije. ${ }^{6}$ Náboženská víra přitom podporuje sociální chování jednotlivců, proto je $\mathrm{v}$ našem zájmu věřit $\mathrm{v}$ Boha a uctívat jej. Tuto argumentaci ovšem Hutcheson odmítá, náš zájem nemůže v našem rozumu produkovat názory a přesvědčení. Není možné být přesvědčen o existenci Boha jen proto, že je to v našem zájmu. Hutcheson zde také navazuje na Shaftesburyho, který podobné koncepce odmítal ve svém nejznámnějším spise. ${ }^{7}$

Stejně jako nemůže být podle Hutchesona zdrojem rozumového přesvědčení osobní sobecký zájem, nemůže být tento zájem také zdrojem určitého typu afekcí, zejména ne lásky. Obraz Boha jako uplácejícího požity a trestajícího hrůzami může motivovat člověka k jednání v jeho vlastním zájmu, ale nemůže vyvolat prožitek lásky. (Oproti obrazu Boha jako dobrotivého otce, který lásku vyvolat může).

Hutcheson nepovažuje lidskou přirozenost za tak antisociální jako Hobbes. V lidské přirozenosti najdeme mnoho pozitivních afekcí - přátelství, lásku apod., které nejsou vyvolány osobním zájmem. Špatné jednání není tak dáno lidskou přirozeností, ale spíše špatnou výchovou, chybnými návyky, v důsledku čehož převáží negativní afekce nad pozitivními.

\footnotetext{
${ }^{5}$ Ibid.

6 Puffendorf, S. On the Duty of Man and Citizen. Printed by John Hayes: Cambridge, 1682. To je Aldridgeova (1946) interpretace. Proti tomu srv. Pufendorf, S., c. d., I.IV.6.

7 Shaftesbury. Inquiry Concerning Virtue. 1699. Shaftesbury zde rozlišil afekce na: 1) přirozené vedoucí $k$ veřejnému dobru, 2) sebeafekce, vedoucí k soukromému dobru, 3) nepřirozené afekce, které jsou $\mathrm{v}$ protikladu jak $\mathrm{k}$ veřejnému, tak $\mathrm{k}$ soukromému dobru.
} 


\section{Mentální geografie}

Dříve než se pustíme do výkladu Hutchesonovy etické koncepce, je nezbytné vymezit základní pojmosloví, které používá - zachytit to, co Hume později nazve mentální geografií.

Hutcheson zde do značné míry vychází z Johna Locka - v roce 1694, kdy se Francis Hutcheson narodil, bylo Lockovi 62 let (Locke umírá v roce 1704). A v době Hutchesonových studií na University of Glasgow byl už Locke uznáván jako jeden z nejvýznamnějších filosofů.

Nejobecnějším pojmem, který pro Hutchesona zahrnuje vše, co se odehrává v imanenci našeho vědomí, jsou ovlionění mysli (Modifications of Mind). Mezi tato ovlivnění pak patří počitky (Sensations), které Hutcheson definuje jako „bezprostředni percepce (Perceptions) slasti a bolesti, při přitomnosti nebo pusobení nějakého objektu nebo události, která je zprostředkována určitou impresí (Impression) na naše těla."8 Zde zároveň vidíme, že percepce jsou obecnější kategorie než počitky, a že imprese chápe Hutcheson jako v zásadě externí příhody vtiskování (im-press) do našeho těla, resp. příslušných smyslových orgánů. Taková představa odpovídá aristotelskoscholastické tradici, ze které Hutcheson vychází a, co se týče analýzy vášní, domnívá se ji prohlubovat a precizovat. Mezi percepce pak patří nejen „vnějšíi” počitky, ale i "vnitřní" cítění. ${ }^{9}$

Hutchesonův text nicméně není, co se týče této mentální geografie, zcela konkrétní. Pojem percepce není zcela jasně definován, zdá se, že percepce je tak cokoli, co vstupuje do mysli z nějakého smyslu. Přitom, jak je zřejmé, krom běžných vnějších smyslů Hutcheson uznává ještě smysly vnitřní, morální, což je klíčovým znakem jeho etické koncepce - sensualismu. Hutcheson píše: „Máme fixně dané číslo pět jako počet našich vnějších smyslü, ačkoli bychom mohli stejně jednoduše obhájit sedm nebo deset. Máme mnoho percepcí, které nemají žádný vztah k nějakému vnějšímu smyslu“.10 Význačnou (zřejmě definitorickou) vlastností produktů smyslů, tedy percepcí, jakožto specifických obsahů našeho vědomí, je to, že jsou do značné míry nezávislé na naší vůli.

Dalším klíčovým typem ovlivnění mysli jsou afekce, o nichž Hutcheson říká: „žádost (Desire) a odpor (Aversion) jsou jedinými čistými afekcemi ve striktním slova smyslu“ ${ }^{11}$

Afekce, tedy žádost a odpor, nejsou vyvolány přímo nějakým objektem nebo událostí, ale vychází z reflexe výhledu na nějaký budoucí př́ijemný nebo nepříjemný počitek. Zároveň se odlišují od všech počitků i tím, že "přímo vedou k jednání“ ${ }^{12}$

\footnotetext{
${ }^{8}$ Hutcheson, F. Essay. str. 49.

${ }^{9}$ Frankena, W. ibid. str. 368.

${ }^{10}$ Hutcheson, F. Essay. str. 5.

11 Ibid., str. 49.
} 
Třetím důležitým termínem jsou vášně (Passions), které jsou podle Hutchesona „zjevně odlišné“ od žádosti a odporu. ${ }^{13}$ Tímto termínem označuje „zmatené počitky slasti nebo bolesti, zapř́činěné nebo doprovázené divokými tělesnými pohyby, které drží mysl $v$ zaujetí současnou záležitostí, s vyloučenim všeho ostatního, a prodlužuje a zesiluje afekci natolik, že to zabraňuje jakémukoli rozvážnému uvažování o našem chování“. ${ }^{14}$ Je tedy zásadní rozdíl mezi chladnou žádostí (calm Desire) osobního dobra a nějakou sobeckou vášní jakou je třeba chamtivost, chtíč, zlost, mstivost, chorobná ctižádostivost apod. Hutcheson se zjevně domnívá, že zde není rozdíl pouze kvantitativní, ale naprosto zásadní rozdíl kvalitativní, píše dokonce, že „nic nemůže být více rozdílné“" než tato dvě ovlivnění mysli. ${ }^{15}$

Dalším významným pojmem jsou pro Hutchesona sklony (Propensity). Sklon nás „velmi často určuje k jednání“, ačkoli se jedná o něco jiného než žádost nebo odpor. Obvykle se vztahuje např. k objektům, které jsou prostředky k něčemu dobrému, ovšem sklon přetrvává i tehdy, pokud daný objekt přestane takovým prostředkem efektivně být. ${ }^{16}$

K podrobnější analýze a rozčlenění všech těchto typů ovlivnění mysli se dostaneme ještě v následujících oddílech tohoto textu.

\section{Hutchesonova Esej}

Hned na začátku své eseje Hutcheson upozorňuje, že zde nebude potřebovat nějaké obsáhlé vyvozování či argumentaci, nebot' „jistotu lze dosáhnout pouze zaostřením pozornosti na to, co se vědomě odehrává v naši mysli“. ${ }^{17}$ Svou práci pak začíná právě vymezením základního pojmového schématu svého zkoumání - na prvním místě je třeba ujasnit si, na co vlastně obecné výrazy "dobrý“ a "zlý" vztahujeme, a to lze právě udělat pozorováním naší vlastní mysli:

„Objekty, jednání nebo události nazýváme dobrými nebo zlými, na základě toho, že jsou př́činami nebo podminkami, zprostředkovaně nebo př́mo, príjemných nebo nepř́iemných percepcí určité vnimavé prirozenosti. "18

\footnotetext{
12 Hutcheson, F. Essay. str. 30, 49.

13 Ibid., str. 49.

14 Ibid., str. 31.

15 Ibid.

16 Ibid., str. 51.

17 Ibid., str. 15. Podobnou tezi lze nalézt i v Hobbes, T. De Corp. I.vi.7; a dále Hobbes. T. Six Lessons to the Professors of the Mathematics. Ep. ded. In: Hobbes, T. The English Works of Thomas Hobbes. Vol. VII. 1839 str. 184.

${ }^{18}$ Hutcheson, F. Essay. str. 15.
} 
Ve své Inquiry podobně říká: „všechny objekty, které jsou schopny vyvolat toto př́ijemno, nazýváme bezprostředně dobrými““. ${ }^{19}$

Tyto vnímavé přirozenosti (sensitive Nature) jsou pak smysly a Hutcheson předpokládá, že ke každému druhu objektů (vizuální, akustické, ...) a k němu příslušejícím požitkům či bolestem, které můžeme vnímat, přísluší specifický smysl (zrak, sluch, ...).

Hutcheson rozlišuje pět druhů smyslů:20

1. Vnější smysly: zrak, sluch, hmat, čich, chut'.

2. Vnitřní smysl: obrazivost (Imagination). Zároveň zdroj přijemných percepcí z pravidelných, harmonických a jednotných objektů.

3. Veřejný smysl (Publick Sense): Zdroj příjemných percepcí ze štěstí druhých,

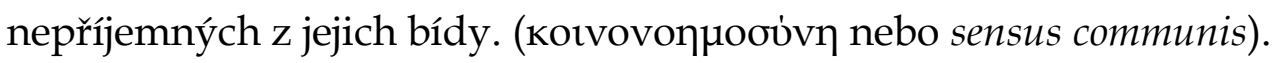

4. Morální smysl: Pomocí toho vnímáme ctnosti a neřesti v sobě a v druhých.

5. Smysl pro čest: Činí vděk druhých za naše dobré činy podmínkou našich příjemných percepcí. V opačném př́ípadě zdroj studu.

Hutcheson také zmiňuje, že jsou zde další percepce, u nichž není jasné, pod které smysly spadají, například: slušnost (Decency), důstojnost (Dignity), přiměřenost (Suitableness) lidské přirozenosti. Můžeme v souvislosti s nimi uvažovat bud' o vnitřním smyslu, o morálním smyslu, nebo je podřadit nějakému novému dalšímu druhu smyslů. ${ }^{21}$

Ve své předchozí práci Inquiry into the Original of Our Ideas of Beauty and Virtue (1725) Hutcheson předkládá estetickou teorii, založenou na předpokladu, že krása je specifickým typem požitku, který je vnímaný zvláštním vnitřním smyslem. Tato teorie byla však zastíněna jeho estetickou koncepcí a nedostalo se jí velké pozornosti. ${ }^{22}$

Všem typům percepcí je společné, že nejsou vưlí ovlivnitelné - objevují se v nás nutně a nemůžeme je vůlí změnit ani zcela potlačit.

Žádosti (Desires) vznikají v naší mysli na základě očekávání zisku dobra v objektech, jednáních nebo událostech pro sebe nebo pro jiné. Opačným případem jsou averze, vznikající z očekávání zla. V důsledku toho můžeme podle Hutchesona rozdělit žádosti (a analogicky averze) na pět druhů odpovídajících pěti druhům smyslů:

\footnotetext{
${ }^{19}$ Hutcheson, F. An Inquiry Concerning the Original of Our Ideas of Virtue or Moral Good. str. 70.

${ }^{20}$ Hutcheson, F. Essay. str. 17-18.

21 Ibid., str. 18.

22 Srv. C. W. Korsmeyer. Relativism and Hutcheson's Aesthetic Theory. str. 319.
} 
1. Žádost smyslových slastí a averze k smyslovým strastem.

2. Žádost slastí obrazivosti či vnitřního smyslu a averze $\mathrm{k}$ těmto strastem.

3. Žádost veřejného blaha a averze $\mathrm{k}$ bídě druhých.

4. Žádost ctnosti a averze $\mathrm{k}$ neřesti.

5. Žádost cti a averze ke studu.

Krom těchto primárních žádostí existují také žádosti sekundární.23 Jsou to ty, které chtějí objekty, které sice neuspokojují žádnou primární žádost, ale jsou užitečné nebo nutné pro dosažení jejich uspokojení. Jedná se tedy zejména o bohatství a moc - o kterých Hutcheson tvrdí, že umožňují uspokojit všechny ostatní žádosti. Tyto jsou však pouhými nástroji, tudíž Hutcheson odmítá jejich zavrhování některými moralisty, kterým oponuje, že až záměr (Intention) a použití těchto nástrojů určuje jejich charakter - lze je totiž použít i k nanejvýš ctnostným účelům. ${ }^{24}$

$\mathrm{V}$ důsledku asociací idejí se pak předmětem žádosti mohou stát i předměty, které žádnou žádost neuspokojují - například vojenské vyznamenání, které je spojeno s ideou cti. Podobně je to s různými objekty, které svou výjimečností vyčleňují svého držitele z davu a poutají na něj pozornost - z toho pak pramení žádost po odlišení se (Desire of Distinction), kterou Hutcheson chápe jako náležející k druhému druhu žádostí, tedy jako související s vnitřním smyslem. ${ }^{25}$

\section{Vyvrácení hédonismu}

Problémem hédonismu se Hutcheson zabýval už i ve své předchozí práci (Inquiry). Zde vymezuje věci bezprostředně dobré, které přímo vyvolávají př́jemné prožitky, věci výhodné (Advantageous), které vedou k těm bezprostředně dobrým, přičemž obojí si žádáme z do̊vodu sebelásky. ${ }^{26}$ Oproti tomu dále říká: „slovo 'morální dobro' (moral goodness) v tomto pojednání označuje ideu určité kvality, pojímané (apprehended) v jednání, která vyvolává schválení (Approbation) a lásku (Love) k jednajícímu, u těch, kteří nezískávají žádnou výhodu (advantage) z tohoto jednání."27 Hutcheson zde staví do kontrastu príjemné na jedné straně s pojmy schválení a láska na straně druhé. Nicméně $v$ dalším textu dochází $\mathrm{k}$ přímé souvislosti mezi př́jemným a morálně dobrým: „význačným smyslem, který nazývám morálním, pocitujeme příjemno při kontemplaci takových jednání u druhých, a jsme určení k lásce

\footnotetext{
${ }^{23}$ Hutcheson, F. Essay. str. 19. (Toto rozlišení může být pravděpodobně odrazem Lockeova slavného rozlišení na primární a sekundární kvality.)

${ }^{24}$ Hutcheson, F. Essay. str. 20.

25 Ibid., str. 21.

${ }^{26}$ Hutcheson, F. Inquiry. str. 70.

27 Ibid., str. 69.
} 
k jednajícímu.“ ${ }^{28}$ Tedy dochází opět ke spojení morálního dobra a s ním spojených pojmů schválení a lásky s př́ijemnem. ${ }^{29}$

V díle, kterým se zde primárně zabýváme (Essay), Hutcheson postupuje jinak a zavádí (Art. III) rozlišení žádostí, a to následujícím způsobem: „Žádosti, v nichž někdo zamýšli či sleduje to, co pokládá za výhodné (advantageous) pro něj samého, nazýváme sobeckými; ty, ve kterých sledujeme to, co pokládáme za výhodné pro jiné a nepokládáme za výhodné pro nás, nebo nesledujeme s ohledem na to, nazýváme veřejné nebo benevolentní žádosti.“30

Hutcheson hned poté reflektuje starou epikurejskou námitku, že "všechny naše žádosti jsou sobecké: neboli to, co každý sleduje nebo prípravuje ve svém jednání, je v konečném důsledku zisk slasti pro něj samého, nebo vyhnutí se jeho vlastní bolesti“. ${ }^{31}$

Hutcheson prohlašuje, že z naší zkušenosti s fenomény jako je přátelství, láska k vlasti nebo k našemu společenství plyne zjevná absurdita tohoto pojetí.

Epikurejskou pozici můžeme nicméně transformovat do podoby, která budí více důvěry. Příznivci této druhé podoby akceptují existenci veřejného smyslu, a to $\mathrm{v}$ př́padech, kdy "pozorovaní štěstí druhých je nutnou podmínkou [vlastní] slasti“ a mluví pak o konjunkci zájmů, tedy říkají, že v takovém případě se: „štěstí druhých stává prostredkem $k$ slasti pozorovatele a $z$ tohoto důvodu, nebo sohledem na tento dưvod si ten přeje štěstí druhého". ${ }^{32}$

Tento argument už vyžaduje komplexnější odpověd' a Hutcheson nejprve opakuje, že toto se děje bez ohledu na naši vlastní vưli (a tedy je to důkazem dobroty Stvořitele). Následně se Hutcheson věnuje podrobnější analýze psychologie žádosti a motivace.

Základní premisou zde je, že žádost je obecně nepř́iemná (uneasy), neboli je vždy zažívána spolu s nepř́ijemným počitkem (Sensation). Tato nepřijemnost je ovšem jiného druhu než nepříjemnost, kterou máme na mysli, když označujeme objekt za zlý, a samozřejmě se jedná o prožitek jiného druhu než př́ijemný počitek, který očekáváme od objektu, jejž označujeme za dobrý. Hutcheson zde pak dochází k několika tvrzením: 33

1. „Žádná žádost jakékoli události není vyvolána výhledem na odstranění nepř́jemného počitku, doprovázejícího tuto žádost samu."

\footnotetext{
${ }^{28}$ Hutcheson, F. Inquiry. str. 72.

${ }^{29}$ Srv. E. Sprague. Francis Hutcheson and the Moral Sense. str. 795-796.

${ }^{30}$ Hutcheson, F. Essay. str. 22.

${ }^{31}$ Cicero. De finib. lib. I

${ }^{32}$ Hutcheson, F. Essay. str. 23.

33 Ibid., str. 24-25.
} 
Vyvolat nějakou žádost mohou jen počitky, které tuto žádost časově předchází (viz. Obrázek 1), nikoli ty, které ji doprovází. Tedy „nepř́iemný počitek, doprovázející a spojený s žádostí samotnou, nemůže být motivem této žádosti, kterou předpokládá". Jelikož je žádost vždy pocitována jako nepř́ijemná, nikdy nevzniká pro ni samou ani s výhledem na její pokračování, ovšem ani opačně, s výhledem na její odstranění.

Zároveň zde je „př́jemný počitek radosti“ (Joy) spojený s uspokojením každé žádosti, spolu s př́jemným počitkem přímo získaným z dobrého objektu, který jsme si žádali a získali. Ale opět platí, že „žádost nikdy nevzniká pouze s výhledem na získání tohoto počitku radosti spojeného s úspěchem nebo uspokojením žádosti“, jinak bychom se mohli ukájet pouhým vyvoláváním a následným uspokojováním žádosti po bezvýznamných a jinak indiferentních, lehce dosažitelných objektech.

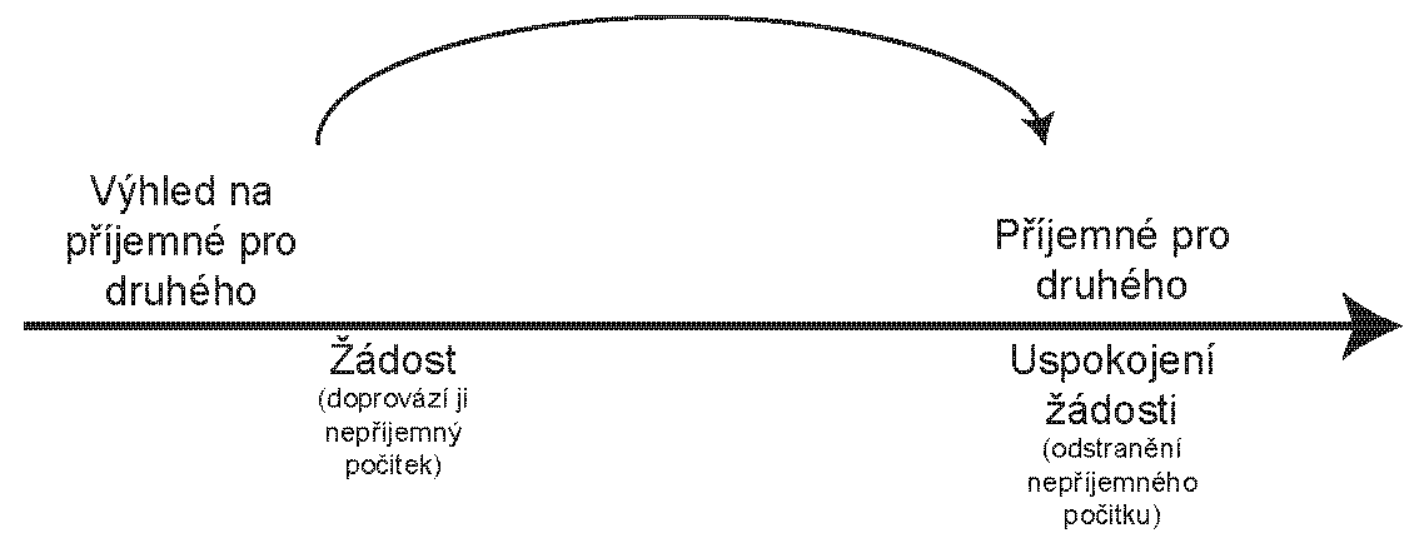

\section{Obrázek 1: Benevolentní žádost}

2. "Je jisté, že žádost po štěstí druhých, kterou pokládáme za ctnostnou, není přimo vyvolána výhledem na nějaké sekulární výhody, bohatství, moc, slast vnějších smyslì, odměnu od božstva, nebo budoucí slasti sebechvály."

Aby toto tvrzení Hutcheson dokázal, vychází z předpokladu, že „žádná žádost jakékoli události nemůže vzniknout bezprostředně či př́mo z názoru jednajícího, že mít tuto žádost je prostředkem knějakému osobnimu dobru“. Tedy žádnou žádost není možné vyvolat př́mo vůlí.

Existuje jen jedna podobná cesta vyvolání žádosti - ta vychází ze sebelásky: v takovém případě „žádost nějaké události, je názorem (Opinion), že tato událost je prostředkem k osobnimu dobru“. V tomto případě se žádost objevuje okamžitě, jakmile zformulujeme takový názor.

Hutcheson uvádí následující příklad: předpokládejme, že by nám Bůh přislíbil štěstí, pokud bude štastná naše země. Potom by z naší sebelásky okamžitě vznikla podřízená žádost po štěstí naší země, jakožto prostředku k našemu vlastnímu štěstí. 
Pokud by nám naopak Bůh přislíbil osobní štěstí nikoli v závislosti na tom, zdali naše země bude štastná, ale na základě toho, že budeme mít žádost po štěstí naší země, pak by byla situace jiná. Sebeláska by v nás nikdy nemohla způsobit žádost štěstí naší země, protože tento fakt není nyní považován za prostředek k našemu štěstí, ale je vưči němu zcela indiferentní. Prostředkem k našemu osobnímu štěstí je v takovém případě výhradně naše žádost štěstí naší země. Ze sebelásky si tudíž můžeme pouze žádat mít tuto žádost, tedy sebeláska může přímo produkovat pouze žádost po tom, mít žádost po štěstí naší země. Ovšem samotná žádost štěstí naší země tím zaručena není.

\begin{tabular}{|c|l|l|l|}
\hline $\begin{array}{l}\text { Původce } \\
\text { žádosti }\end{array}$ & $\begin{array}{l}\text { Produkovaná } \\
\text { žádost }\end{array}$ & Prostředek & Cíl \\
\hline Sebeláska & $\begin{array}{l}\text { Žádost štěstí } \\
\text { naší země }\end{array}$ & Štěstí naší země & Osobní štěstí \\
\hline Sebeláska & $\begin{array}{l}\text { Žádost prádosti štěstí } \\
\text { naší země }\end{array}$ & $\begin{array}{l}\text { Žádost štěstí naší } \\
\text { země }\end{array}$ & Osobní štěstí \\
\hline
\end{tabular}

Tento př́iklad podle Hutchesona ukazuje, že pokud bychom neměli jinou afekci (Affection) než sebelásku, pak bychom si mohli žádat štěstí druhých pouze pokud bychom jej chápali jako prostředek k našemu vlastnímu štěstí. Pokud by naopak poznaným prostředkem $\mathrm{k}$ našemu štěstí bylo pocitování určitých žádostí, pak by to v nás vyvolalo pouze žádost pocitovat tyto specifické žádosti, nevyvolalo by to v nás tyto žádosti samotné. ${ }^{34}$

Ovšem vytvořit v nás určitou žádost nemůže ani žádost ji mít, tvorba žádostí nepodléhá podle Hutchesona vůli. Jinak by úplatek mohl vyvolat jakoukoli žádost, a Hutcheson dokonce ř́ká, že bychom mohli být najati milovat či nenávidět jakéhokoli člověka. ${ }^{35}$

Hutcheson neodmítá, že v některých případech můžeme chtít štěstí druhých jako prostředek k vlastnímu štěstí, ovšem není tomu tak ve všech případech. Existuje skutečná benevolence nezávislá na výhledu k osobnímu dobru, kterou Hutcheson označuje jako ctnostnou (Virtuous). ${ }^{36}$

\footnotetext{
${ }^{34}$ Hutcheson, F. Essay. str. 25.

35 Ibid., str. 26.

36 Ibid., str. 27.
} 
Tak se Hutcheson dostává k další významné námitce (Art. IV): „Nemůže být naše benevolence prinejmenším žádost štěstí druhých, jakožto prostředku kzískání požitku z veřejného smyslu, z kontemplace jejich blaženosti?". 37

Hutcheson nejprve konstatuje, že pak by byla situace podobná jako $\mathrm{v}$ případě žádosti hazardního hráče - tomu nejde o výhru, nýbrž je to samotná hazardní hra, co ho uspokojuje. Tedy tato námitka spočívá v tom, že v benevolenci může jít o totéž, nikoli o štěstí druhých, ale upokojení naší žádosti po benevolenci jako takové. Tedy opět by prvotním zdrojem takové žádosti byla sebeláska.

Hutcheson odpovídá na tuto námitku nejprve poukazem na naši vlastní zkušenost. Těží přitom z již vyložené koncepce, že každá žádost je svou povahou nepříjemná, tedy výše uvedená námitka vlastně chápe jako motiv benevolentního jednání odstranění této nepř́ijemnosti. To podle Hutchesona neodpovídá naší vlastní zkušenosti s motivací při benevolentním jednání.

Dále Hutcheson uvádí následující argument: předpokládejme, že při setkání s člověkem v nouzi by nám božstvo nabídlo bud' 1) odstranění všech myšlenek (obliterate all Ideas) na tuto osobu v nouzi, nicméně ponechalo by ji v bídě, nebo 2) pomoc této osobě a ulehčení její nouze. Pokud bychom přijali výše uvedenou koncepci, pak by $\mathrm{v}$ obou případech došlo kodstranění nepř́ijemna spojeného s benevolentní žádostí a tudíž bychom museli být zcela indiferentní mezi těmito dvěma variantami a ani jednu bychom nepreferovali. 38

Další podobný argument zní: pokud by se božstvo rozhodlo nás okamžitě zničit, takže bychom nebyli schopni pocit'ovat ani slast ani bolest, ovšem záleželo by na našem rozhodnutí v okamžiku našeho konce, zdali naše děti, přátelé či země budou št'astni, pak pokud bychom přijali výše uvedenou koncepci benevolence, museli bychom opět být zcela indiferentní mezi těmito dvěma variantami a ani jednu nepreferovat. Jakou touhu bychom mohli mít po uspokojení, které by mělo žádné či zcela zanedbatelné trvání? ${ }^{39}$

Stejně tak Hutcheson v tomto místě poměrně stručně odmítá možnost, že naše rozhodnutí by $\mathrm{v}$ tomto případě směřovalo ke štěstí druhých, ovšem nikoli na základě skutečné benevolence, ale $\mathrm{v}$ důsledku "zmatení idejí“, podobného, jako když každého nenávidící boháč touží po dalším nárůstu svého bohatství i na smrtelné posteli. ${ }^{40}$

Problémem, na který dále Hutcheson upozorňuje, je samotná povaha žádosti, která je sice chápána jako počitek (definuje ji jako „nepř́ijemný počitek při absenci dobra“), ovšem je to počitek zásadně odlišný od všech ostatních počitků. S tím pak

\footnotetext{
37 Ibid.

${ }^{38}$ Ibid.

${ }^{39}$ Hutcheson, F. Essay. str. 28.

${ }^{40}$ Ibid.
} 
také souvisí obtížnost přijetí konceptu nezainteresované žádosti (disinterested Desire). Přitom se však podle Hutchesona setkáváme s žádostí, která nemírí přímo na náš osobní prospěch, velmi často (opět je příkladem žádost posmrtné slávy v okamžiku smrti). ${ }^{41}$

Zároveň Hutcheson poznamenává, že motivace zištným zájmem, například ve výše zmiňované situaci, kdy je božstvem přislíbena odměna tomu, kdo bude mít ctnostné žádosti, může vést k žádosti mít tyto ctnostné žádosti, a tudíž k jejich pěstování a kultivaci. Tedy odměny a tresty přislíbené v Písmu mají velmi dobrý smysl. ${ }^{42}$ Navíc můžeme poznamenat, že Hutcheson je si správně vědom, že ačkoli naše žádosti nemohou být př́mo vyvolány naší vůlí, přesto je můžeme nějak v dlouhodobém horizontu měnit, kultivovat, což umožňuje např́ílad výchovu a aktivní formování charakteru a Hutcheson v tomto přejímá klasickou koncepci Aristotelovu.

\section{Afekce a vášně}

Hutcheson po výše uvedené analýze počitků (Sensation) následně přistupuje ke zkoumání afekcí (Affection), přičemž, aby zabránil nedorozumění, poskytuje následující definice: počitek (Sensation) je „přímá nezprostředkovaná percepce požitku či bolesti“; afekce pak je "percepce požitku či bolesti, nikoli vyvolaná přímo přítomností nebo působením objektu či události, ale naší reflexí či aprehenzí jejich současné nebo jisté budoucí existence, tedy že jsme si jisti, že objekt nebo událost v nás vyvolá tento přímý počitek."

Hlavními druhy afekcí jsou žádost (Desire) a odpor (Aversion), následně také radost (Joy), smutek (Sorrow) případně zoufalství (Despair). Od prosté afekce pak Hutcheson odlišuje její specifickou podobu nazvanou vášeň (Passion), kterou definuje jako „zmatený počitek (Sensation) požitku či bolesti, doprovázený výraznými tělesnými pohyby, které podržují mysl zaměstnanou aktuální záležitostí a vylučují vše ostatní, jež prodlužuje a posiluje afekci někdy až k takovému stupni, který zabraňuje rozvážnému uvažování o našem chování." 43

Hutcheson následně také konstatuje, že existuje zásadní rozdíl mezi chladnou žádostí po dobru (at' už vlastním nebo veřejném) a jednotlivými vášněmi, týkajícími se bezprostředně předmětů našich smyslů (hlad, zlost atd.). Navíc tyto dva prožitky mohou stát proti sobě. Proto se učíme ovládat své vášně: skrze častou reflexi a návyk získáváme sílu je mít pod kontrolou. Zároveň Hutcheson upozorňuje, že toto jeho

\footnotetext{
${ }^{41}$ Hutcheson, F. Essay. str. 29.

42 Ibid.

43 Ibid., str. 31.
} 
rozlišení odpovídá scholastickému rozlišení mezi Appetitus rationalis a Appetitus sensitivus. Kořeny tohoto rozlišení lze pak vysledovat až k Aristotelovi. ${ }^{44}$

Chladná žádost po veřejném dobru může být směřována $\mathrm{k}$ dobru jednotlivých osob, společenství, či obecné abstraktní komunity, druhu nebo systému. V případě obecného abstraktního cíle se pak podle Hutchesona jedná o universální chladnou benevolenci. ${ }^{45}$

Jednotlivé positivní afekce a jednotlivé konkrétní benevolence podléhají pak schválení morálním smyslem s ohledem na universální chladnou benevolenci. Jen pokud je tato nejabstraktnější benevolence nadřazena ostatním afekcím a vášním, je možné podle Hutchesona dosáhnout trvalého souladu se sebou samým (SelfApprobation). ${ }^{46}$

Hutcheson následně v souvislosti s tím formuluje definice svých základních morálních pojmů, které uvádíme v př́iloze.

\section{Vášně nepodléhají vůli}

V dalším oddíle se Hutcheson věnuje vášním (Passions), které se vyznačují zejména tím, že nepodléhají volní kontrole. Hutchesonův argument je modifikovanou formou argumentu sporem: předpokládejme, že bychom si mohli svobodně zvolit náš vlastní stav s ohledem na tyto vášně (např. jestli pocitujeme strach či nikoli), zkoumejme nyní, jaký stav bychom si v běžných případech zvolili. Při takovém zkoumání podle Hutchesona uvidíme, že pokud bychom mohli, určitě bychom si zvolili jiný stav, než běžně v takových situacích zažíváme. ${ }^{47}$

Například pokud jsme v situaci, kdy víme, že nám hrozí nějaké zlo, určitě napneme síly, abychom mu zabránili, ale určitě bychom se sami nerozhodli pocit’ovat nepřijemný prožitek strachu, který může být někdy horší (například v př́ípadě dlouhého trvání) než zlo samotné. ${ }^{48}$

Podobné je to ale $\mathrm{i} v$ případě očekávání dobra, kdy v nás vznikají nepřijemné vášně jako nedočkavost, rozmrzelost, pro které bychom se sami nikdy, pokud bychom mohli, svobodně nerozhodli. ${ }^{49}$

Protože vznikají takto samovolně a někdy nejsou ani k našemu prospěchu, nazývá je někdy Hutcheson zmatenými (confused) počitky.

\footnotetext{
${ }^{44}$ Hutcheson, F. Essay. str. 32.

45 Ibid.

46 Ibid., str. 33.

47 Ibid., str. 39.

48 Ibid., str. 41.

49 Ibid., str. 42.
} 
Pokud tedy Hutcheson ukázal, že tyto vášně nepodléhají naší vůli a vznikají v nás vlastně samovolně, snaží se zodpovědět i otázku, proč je naše přirozená konstituce taková, že v nás tyto vášně vznikají, jaký je tedy jejich smysl. Na to nedává Hutcheson jednoznačnou odpověd', odvolává se na moudrost našeho stvořitele, souvislost s našimi ostatními nedokonalostmi, které tyto zmatené vášně mohou nějak doplňovat či snad kompenzovat. ${ }^{50}$ Takovou pomocnou roli může hrát třeba hlad v případě výživy nebo bolest, která může mít ochrannou funkci vzhledem k poškození těla. ${ }^{51}$ Podobně vztek může být ochranou před nespravedlností. ${ }^{52}$ Silné vášně jsou spojeny s výchovou a péčí o děti. Podobně podporují i společenský život, protože podle Hutchesona „štěstí lidského života nemůže být dosaženo bez společnosti a vzájemné pomoci, i mimo hranice rodiny. "53 Naše štěstí tedy vyžaduje rovnováhu mezi žádostmi veřejnými a soukromými, a vůlí nekontrolované vášně umožňují tuto rovnováhu nastolovat.

Hutcheson zde $\mathrm{v}$ duchu aristotelské tradice klade důraz právě na udržování tohoto rovnovážného stavu vášní, nejen s ohledem na jejich vzájemné vztahy, ale i na sílu každé z nich, která má být kontrolována, aby byla udržena ve správných mezích. ${ }^{54}$ Právě v této rovnováze pak tkví lidské štěstí. ${ }^{55}$

\section{Sklony}

Jak už bylo řečeno, sklon (Propensity) nás podle Hutchesona „velmi často určuje k jednání", přestože se jedná o něco jiného, než žádost nebo odpor. Sklon se vztahuje k objektům, které jsou prostředky k něčemu dobrému, ovšem přetrvává i tehdy, pokud daný objekt přestane takovým prostředkem být. Příkladem může být zlost (Anger), která směřuje nejen k odstranění vlastního poškození a dosažení přměřené náhrady, př́ípadně zajištění bezpečí do budoucnosti, ale také k poškození či zranění útočníka, a to i tehdy, když tím nemůže být dosaženo žádného dobra, či zabráněno nějakému zlu. ${ }^{56}$ Stejně tak máme sklon k útěku či výkřiku v případě, že se objeví nějaké nebezpečí, a to i tehdy, pokud útěk nebo výkřik nemůže naši situaci zlepšit (či by ji naopak ještě zhoršil). Dalším podobným př́ikladem je sklon ke slávě, o kterou lidé usilují, i kdyby nebyla k ničemu jinému dobrá.

Tyto sklony nazýváme vášněmi (Passion), pokud se vyskytují bez racionálních žádostí. Pokud doprovázejí racionální žádosti, pak tyto nazýváme vášnivými žádostmi (passionate). Tyto vášně jsou podle Hutchesona stejně inteligibilní jako

\footnotetext{
50 Hutcheson, F. Essay. str. 44.

51 Ibid., str. 45.

52 Ibid., str. 46.

53 Ibid., str. 45.

54 Ibid., str. 46.

55 Ibid., str. 47.

56 Ibid., str. 52.
} 
většina ostatních součástí naší konstituce, jsou stejně dobře pozorovatelné a zkoumatelné. ${ }^{57}$

\section{Dělení vášní}

V další části svého textu se Hutcheson zabývá přesným rozdělením vášní. Nejprve rekapituluje př́istup Cicerův a následně Malebranchův - což je autor, na kterého svou koncepcí explicitně navazuje. Ohledně scholastické tradice se jen zmiňuje, že tato nejde př́iliš za přístupy obdivovaného Aristotela. ${ }^{58}$

Sám Hutcheson pak navrhuje dělení vášní na několik tříd, a v rámci každé třídy pak na několik skupin.

\section{První třída vášní}

První třída vášní se týká našeho vlastnîho jednání a tyto vášně jsou vyvolávány naším morálním smyslem nebo smyslem pro čest.

Morální smysl s ohledem na naše vlastní jednání se projevuje podle Hutchesona v následujících situacích: ${ }^{59} 1$ 1) když si představíme nebo vidíme (například při divadelním představení) morálně dobré jednání, objeví se v nás touha jednat stejným zpusobem; 2) pokud jsme jednali dobrým způsobem, dostaví se uspokojení (Triumph of Joy); 3) pokud jsme ve své jednání zklamali, na základě sobectví nebo opomenutí, pak litujeme tohoto jednání.

4) Pokud si naopak představíme nebo vidíme morálně špatné jednání, pak cítíme zdrženlivost (Reluctance); 5) pokud jsme takové jednání spáchali, cítíme opět smutek ve formě lítosti; 6) pokud jsme naopak odolali takovému pokušení, cítíme vnitřní uspokojení (secret Joy) a sebeuspokojení (Self-Approbation).

Dalších šest druhů vášní pocit'ujeme podle Hutchesona s ohledem na smysl pro čest (Sense of Honour):60 1) pokud nastanou okolnosti, v nichž bychom mohli dojít cti, pak cítíme žádost; 2) pokud jí dosáhneme, pak uspokojení; 3) pokud jsme zklamaní pak smutek. 4) Pokud chápeme nějaké jednání nebo situaci jako nečestnou, pak cítíme odpor; 5) pokud vnímáme pokušení se na ní podílet, pak pocitujeme rezervovanost (Modesty) nebo stud (Shame); 6) pokud překonáme toto pokušení, cítíme uspokojení.

\section{Druhá třída vášní}

Druhá třrida vášní, kterou Hutcheson určuje, se vztahuje ke štěstí nebo bídě druhých, v souvislosti s jejich morálními kvalitami. ${ }^{61}$ Pokud nedochází ke konfliktu

\footnotetext{
57 Hutcheson, F. Essay. str. 52.

58 Ibid., str. 49-50.

59 Ibid., str. 55.

60 Ibid.

61 Ibid., str. 56.
} 
zájmů (například naše štěstí v konfliktu se štěstím jiných) 1) přirozeně toužíme po štěstí pro druhé, 2) radujeme se, pokud štěstí dosáhnou (Congratulation), 3) a cítíme smutek, pokud jej ztratí, což se nazývá soucit (Compassion).

Stejně tak toužíme, aby ostatní dosáhli ctností. Podle Hutchesona nám náš morální smysl předkládá ctnost jako největší štěstí pro člověka, který jí dosáhl. 4) Pokud nastane př́ležitost ke ctnostnému jednání, přejeme si, aby se o to druhý pokusil, 5) aby uspěl, a pokud se tak stane, cítíme uspokojení, 6) pokud selže, pak smutek.

$\mathrm{V}$ př́ipadně pohledu na pokušení druhého ke špatnému jednání cítíme odpor, pokud druhý nepodlehne, cítíme radost, pokud podlehne, pak smutek.

\section{Třetí třída vášní}

Třetí třídou vášní jsou veřejné afekce (Publick Affections) spojené s morálními percepcemi ctnosti nebo neřesti jiných jednajících lidí. Tyto se projevují v situaci, kdy vidíme morálně ctnostného člověka a v souvislosti s tím mu přejeme dosažení štěstí, v míře vyšší než u předchozí (druhé) trř́dy vášní. Naopak neštěstí takového člověka $v$ nás vyvolává vyšší míru smutku, lítosti a neuspokojení. Hutcheson na tomto místě také kritizuje klasické tragédie, které zobrazují dokonale ctnostné muže v nejvyšším stupni nešt́astné, a tak podkopávají důvěru lidí v Boží prozřetelnost. ${ }^{62}$

Naopak vyhlídka na dobro získané člověkem zcela zlovolným vyvolává u pozorujícího člověka odpor (Aversion) nebo žádost nenaplnění této vyhlídky. Pokud se tato vyhlídka nenaplní, vyvolá to radost, víru v prozřetelnost a upevnění ctností. Naopak naplnění těchto vyhlídek vyvolává smutek, nedůvěru a podezíravost. ${ }^{63}$

Hutcheson zdůrazňuje, že tento typ vášní byl obvykle filosofy zaměňován s jednoduchými sobeckými vášněmi, přitom se jedná o daleko složitější a komplexnější prožitky. Ty pak byly využívány zejména v dramatickém a literárním umění. ${ }^{64}$

\section{Čtvrtá tř́́da vášní}

Čtvrtá třída vášní vzniká opět z veřejných afekcí při pozorování jednání lidí nějakým způsobem spřízněných, at' už příbuzných nebo na základě ưradu, či naopak nespř́zněných na základě nějaké předchozí újmy.

Hutcheson tvrdí, že pokud jsou tyto vztahy mezi jednajícími známé, pak morální kvality jejich jednání jsou podstatně odlišné a také vyvolané vášně jsou více rozlišené. Opět pak také poznamenává, že tento typ vášní je využíván dramatickými

\footnotetext{
62 Hutcheson, F. Essay. str. 57.

63 Ibid., str. 59.

64 Ibid., str. 59-61.
} 
autory, ale i v oblasti rétoriky, kde je vyvoláván efekt použitím komplikovaných figur a kontrastu či sjednocení. ${ }^{65}$

Příkladem těchto vášní je pak vděčnost, která vyvolává prožitky lásky a úcty; naopak nevděčnost vyvolává odpor. Odpuštění předchozí újmy a ještě více oplácení zla dobrem se nám jeví vynikajícím a krásným a vyvolává silnou lásku k odpouštějícímu. Lituje-li ten, kdo újmu způsobil, svého činu, pak vyvolává soucit a dobrou vůli. Pokud nelituje, pak nenávist a opovržení.

\section{Pátá třída vášní}

Do páté tř́idy řadí Hutcheson ty vášně, v nichž se některá z předchozích vášní mísí se sobeckými vášněmi. Toto promíšení obvykle není rozpoznatelné jednajícím, pokud je pod vlivem zuřivosti (Rage), nicméně v klidu jej pozorný člověk dokáže rozpoznat jak u sebe prostřednictvím reflexe, tak pozorováním u jiných.

Toto roztřídění vášní zároveň podle Hutchesona ukazuje další důležitou věc: někteří autoři se domnívali, že člověk byl stvořen s přirozeností, která spojuje požitky s jednáními zakázanými nebo přinejmenším indiferentními k Zákonu, proto poslušnost musí být zajištěna výhradně sankcemi. ${ }^{66}$ Hutcheson se domnívá, že z jeho analýzy je zřejmé, že toto chápání je chybné a říká: „Každá vášeň nebo afekce je ve svém umírněném stupni nevinná, mnoho je přimo př́větivých a morálně dobrých: máme počitky a afekce vedoucí nás kveřejnému dobru, stejně jako ksoukromému, kctnosti, stejně jako k vnějšimu požitku."

Hutcheson tak vlastně odmítá už od Platóna se datující rezervovaný postoj ke smyslovosti a snaží se ji v morální oblasti rehabilitovat.

\section{Rozlišení typů žádostí se zřetelem na zkušenost}

První typ žádostí zahrnuje ty, které jsou založeny na nepř́ijemném počitku, který pocit'ujeme bez ohledu na nějaké předchozí mínění (Opinion) nebo ohledně dobra objektu, který umožňuje danou žádost uspokojit. Tyto nepř́ijemné počitky pocit́ujeme podle Hutchesona aniž bychom předem měli ponětí (Notion) o tom charakteru dobra v objektu, který tyto nepřijemné počitky spojené s žádostí dokáže potlačit. Takové žádosti nazývá apetity (Appetites). Dobro příslušných objektů schopných uspokojit apetit pak spočívá obvykle právě jen v této schopnosti odstranit nepřijemný počitek spojený s žádostí, v ničem jiném.

\footnotetext{
65 Hutcheson, F. Essay. str. 62.

66 Toto chápání zákona je možné najít mj. v Locke, J. Essay concerning human understanding. II.xxviii.6
} 
Příkladem apetitu jsou pro Hutchesona hlad a žízeň, sexuální žádost, ale také potřeba společnosti, která se neprojevuje okamžitě, ale v případě absence společnosti po delší dobu je jasně pocitována. ${ }^{67}$

U jiných typů žádostí je situace podle Hutchsona jiná: bez předchozího seznámení s příslušnými objekty tyto žádosti nikdo nepocit’uje. Jedná se například o př́jemné vưně, krásné věci, bohatství, moc - u nich je potřeba předběžné seznámení se s nimi, určitá zkušenost, aby v nás byla vyvolána tato žádost. Podobná situace je podle Hutchesona ale i v př́ipadě ctnosti (Virtue) a cti (Honour).

Uspokojení (stejně jako zklamání v případě neúspěchu) je v poměru k síle žádosti. Podobně př́jemný počitek z uniknutí objektu vyvolávajícího averzi je v poměru k síle averze. Síla žádosti či averze je však u žádostí, které nejsou apetity, dána předchozí zkušeností. Z toho pak pro Hutchesona plyne nemožnost posuzování stupňů štěstí či neštěstí (Misery) u druhých, jelikož neznáme tyto jejich předchozí zkušenosti. Hutcheson také zdůrazňuje, že na tomto výkladu je jasně patrné, jak jsou pro míru našeho štěstí a neštěstí důležité předchozí zkušenosti a na jejím základě zformované názory. ${ }^{68}$

Hutcheson při tom také přesně pozoruje, že východiskem je zde názor nebo zhodnocení (Apprehension) dobra, toto pak určuje sílu žádosti, tato síla žádosti je pak hlavním faktorem určujícím sílu uspokojení. Stejně tak je to v př́ípadě averzí. Míra našeho uspokojení pak není určována výhradně charakteristikami dosaženého objektu nebo události, ale našimi předchozími názory a hodnoceními. Tyto názory a hodnocení jsou pak posilovány spojováním idejí (Association) a různými společenskými silami, což vede k „zesilování vášní až do extravagantních úrovní, mimo proporce skutečného dobra (real Good) vobjektu“, přičemž Hutcheson zmiňuje i možný vliv "tajných názorü“ (secret Opinions). ${ }^{69}$ Takto silné vášně pak není možné překonat ani rozumovou úvahou, což je podle Hutchesona př́ičinou situace, kdy někdo ví, že je nějaké jednání špatné, ale přesto tak jedná.

Hutcheson tedy ve své analýze předjímá jednak (sociologickou) problematiku dynamiky skupinového jednání - tedy právě situace, kdy skupinová interakce podporuje určité vášně a následně určitá jednání, ke kterým by bez této interakce nedošlo. ${ }^{70} \mathrm{Na}$ druhé straně pak je možné ve zmínce o "tajných vášních“ vidět odkaz na podvědomí, jehož vliv byl odhalen až psychoanalýzou S. Freuda; ovšem to, že některá jednání není možné plně vysvětlit $z$ toho, co jsou naše běžná přesvědčení a názory, bylo zřejmé už i například Hutchesonovi. ${ }^{71}$

\footnotetext{
67 Hutcheson, F. Essay. str. 67.

68 Ibid., str. 68.

69 Ibid., str. 69.

${ }^{70}$ Forsyth, D. R. Group dynamics. Belmont : Wadsworth, 2009.

${ }^{71}$ Fine, R. The history of psychoanalysis. Northvale : Aronson, 1990.
} 
Naše veřejné žádosti jsou zasaženy tímto zmateným směšováním idejí stejně tak, což je podle Hutchesona příčinou toho, že v souvislosti se soucitem je zlo horší pro pozorovatele než pro trpícího. ${ }^{72}$ Stejně tak je někdy důsledkem i přehnaný důraz na některé konkrétní ctnosti (propagace pravého náboženství, společenskost), zatímco jiné jsou kvůli tomu opomíjeny a nakonec i jejich vlastní účel je přitom opomíjen. ${ }^{73}$ Hutcheson zde ale opět neříká, co tímto cílem (the very End) ctností je a ponechává na čtenáři, aby si to dovodil.

Tímto také Hutcheson vysvětluje absolutně zlé afekce, což jsou pro něj zášt' (Rancour), nezaujatá zlovolnost (disinterested Malice), msta (Revenge) a misantropie (Misanthropy). ${ }^{74}$

Obecně je podle Hutchesona možné říci, že naše ideje a názory se formují často velmi zbrkle a neuspořádaně a naše afekce jim dobře odpovídají. Tedy pokud jsou naše ideje a názory týkající se druhých spravedlivé, pak i naše afekce jsou dobré. Ale pokud popustíme uzdu představivosti a imaginaci, pak naše afekce jim také svou nerozumností odpovídají. To se týká třeba případi̊, kdy si v důsledku takto zmatených idejí představujeme celé národy jako absolutně zlé, při jakékoli zmínce o nich si asociujeme ideje krutosti či pohanskosti a opakovaným reflektování našich příkoří se zatvrzujeme v nenávisti a považujeme je za bezprostředně zlovolné. ${ }^{75}$

\section{Závěr}

Etika Francise Hutchesona je založena na předpokladu, že nikoli rozum, ale afekce jsou tím, co je pro lidskou moralitu fundujícím. Nejedná se jen o jeho opakované upozornění, že ti nejrozumnější zdaleka nebývají i nejmorálnějšími. ${ }^{76}$ Afekce jsou zároveň nezainteresované, to znamená, že je nelze ovlivňovat zájmy - jak bylo řečeno výše, představa, že by bylo možné si někoho najmout, aby nás miloval nebo nenáviděl, je absurdní. Pouze nezaujaté zhodnocení morálních kvalit člověka před námi může vyvolat (morální) lásku. Lidské afekce jsou od své přirozenosti z velké části dobré, jejich zkoumáním můžeme objevit způsoby jednání, které vyvolávají tyto afekce, a tato jednání jsou pak ctnostná. Tímto způsobem se ze hry z velké části dostávají také odměny a tresty, které byly kritizovanou součástí náboženské etiky Clarka a Wollastona.

Hutchesonova Esej pak poskytuje přehlednou analýzu afekcí. Afekce je nejprve definována jako percepce požitku či bolesti, která není přímo vyvolána nějakým objektem, ale je vyvolána reflexí či aprehenzí současné či budoucí existence nějak

\footnotetext{
72 Hutcheson, F. Essay. str. 71.

73 Ibid., str. 72.

74 Ibid., str. 72.

75 Ibid., str. 72.

${ }^{76}$ Aldridge, A. O.. A Preview of Hutcheson's Ethics. 1946. str. 154.
} 
působícího objektu. Hlavními afekcemi jsou pak žádost, odpor, v druhé řadě pak radost a smutek. Specifickým a důležitým typem afekce jsou vášně (a následně sklony). Hutcheson následně dělí vášně do několika skupin, které pak detailně analyzuje. Důležitým znakem vášní je, že nepodléhají volní kontrole, tedy vycházejí z naší přirozenosti, tak jak je konstituována naším Stvořitelem; všechny vášně tedy mají nějakou funkci, kterou ale ještě nemusíme dobře chápat.

Pro Hutchesona je tak důležité našim vášním porozumět, naučit se je udržovat v rovnovážném stavu, naučit se jednat tak, abychom vyvolávali pozitivní afekce, jejichž základ byl v naší přirozenosti předpřipraven moudrým Stvořitelem, nebot' v tom tví ctnostné jednání i lidské štěstí. 


\section{Př́loha: Hutchsonovy etické definice a axiomy}

Definice základních morálních pojmů (3477)

\begin{tabular}{|c|c|c|}
\hline & Pojem & Definice \\
\hline 1 & Přirozené dobro & Požitek (Pleasure) \\
\hline 1 & Přirozené zlo & Bolest (Pain) \\
\hline 2 & $\begin{array}{l}\text { Přirozeně dobré } \\
\text { (zlé) objekty }\end{array}$ & $\begin{array}{l}\text { "ty, které jsou schopné, bezprostředně nebo } \\
\text { zprostředkovaně, poskytovat požitek (bolest)" }\end{array}$ \\
\hline 3,4 & $\begin{array}{l}\text { Absolutní dobro } \\
\text { (zlo) }\end{array}$ & $\begin{array}{l}\text { „to, co obsahuje více dobra, než je zapotřebí ke } \\
\text { kompenzaci veškerého jeho zla“ (u zla - naopak) }\end{array}$ \\
\hline 5 & $\begin{array}{l}\text { Relativní dobro } \\
\text { (zlo) }\end{array}$ & $\begin{array}{l}\text { "konkrétní dobro nebo zlo, které nekompenzuje } \\
\text { všechny protikladné průvodní jevy nebo } \\
\text { následky"78 }\end{array}$ \\
\hline 6 & $\begin{array}{l}\text { Universální } \\
\text { dobro (zlo) }\end{array}$ & $\begin{array}{l}\text { "směřuje ke štěstí celého systému vnímavých } \\
\text { bytostí (u zla - naopak) }\end{array}$ \\
\hline 7 & Částečné dobro & „směřuje ke štěstí části tohoto systému“ \\
\hline 8 & $\begin{array}{l}\text { Soukromé } \\
\text { dobro }\end{array}$ & „dobro jednajícího člověka“ \\
\hline 9 & $\begin{array}{l}\text { Složené } \\
\text { (Compound) } \\
\text { dobré objekty či } \\
\text { události }\end{array}$ & "obsahují síly více dober zároveň" \\
\hline 10 & $\begin{array}{l}\text { Smíšené } \\
\text { (Mixed) objekty }\end{array}$ & „obsahují zároveň síly dobra a zla“ \\
\hline 11 & $\begin{array}{l}\text { Nejvyšší nebo } \\
\text { nejdokonalejší } \\
\text { dobro }\end{array}$ & $\begin{array}{l}\text { „je ta posloupnost nebo rozvrh (Scheme) } \\
\text { událostí, která obsahuje největší součet } \\
\text { (Aggregate) štěstí v celku, nebo více absolutního } \\
\text { universálního dobra, než jakýkoli jiný rozvrh, po }\end{array}$ \\
\hline
\end{tabular}

77 V závorce uvádíme číslo strany v Hutcheson, F. Essay.

78 Tedy relativní dobro může být podle Hutchesona absolutním zlem. 


\begin{tabular}{|c|c|c|}
\hline & & odečtení všech zel, která jsou s tím propojena." \\
\hline 12 & Dobré jednání & $\begin{array}{l}\text { „jednání je v morálním smyslu dobré, pokud } \\
\text { vychází z benevolentní afekce, či ze } \\
\text { zamýšleného absolutního dobra pro druhé“ }\end{array}$ \\
\hline 13 & Zlé jednání & $\begin{array}{l}\text { „jednání je morálně zlé, pokud vychází ze } \\
\text { záměru absolutního zla, universálního nebo } \\
\text { částečného; nebo ze sledování soukromého nebo } \\
\text { částečného relativního dobra, o němž mohl } \\
\text { [jednající] vědět, že vede k universálnímu } \\
\text { absolutnímu zlu“ }\end{array}$ \\
\hline 14 & $\begin{array}{l}\text { Složená morální } \\
\text { dobrost } \\
\text { (Goodness) a } \\
\text { zlost. }\end{array}$ & $\begin{array}{l}\text { "zahrnuje současně více druhů [dobrosti]“; } \\
\text { například zároveň lásku k bližním a vděk } \\
\text { k Bohu (u zla naopak) }\end{array}$ \\
\hline 15 & $\begin{array}{l}\text { Dobří či zlí } \\
\text { jednající }\end{array}$ & $\begin{array}{l}\text { „jednající jsou označeni za morálně dobré či zlé, } \\
\text { podle jejich afekcí, jednání a pokusu o jednáni““ }\end{array}$ \\
\hline
\end{tabular}

\section{Koroláry}

Některé z výše uvedených definic doplňuje Hutcheson pomocnými tvrzeními (koroláry):

Cor. 5. Relativní dobro může být absolutním zlem.

Cor. 8.1: Částečné nebo soukromé dobro může být universálním zlem.

Cor. 8.2: Pokud jsou částečná nebo soukromá dobra navzájem nevinná (Innocent), pak jsou universálními dobry.

\section{Axiomatika a algebra dobra}

Po výše uvedených definicích následuje Hutchesonův výčet axiomů, neboli zákonů chladné žádosti (37):

1. Sobecké žádosti sledují pouze osobní dobro jednajícího.

2. Benevolentní nebo veřejné (publick) žádosti sledují dobro druhých. 


\begin{tabular}{|r|l|}
\hline 3. & $\begin{array}{l}\text { Síla žádosti je v proporci k představované kvantitě dobra pro } \\
\text { jednajícího nebo související osobu. }\end{array}$ \\
\hline 4. & $\begin{array}{l}\text { O smíšené (mixed) objekty je usilováno žádostí, jejíž síla odpovídá } \\
\text { nadbytku dobra (a vice versa v př́padě nadbytku zla). }\end{array}$ \\
\hline 5. & Stejné množství dobra a zla ukončí všechny žádosti a averze. \\
\hline 6. & $\begin{array}{l}\text { O složený objekt je usilováno silou žádosti odpovídající sumě dobra (a } \\
\text { vice versa v př́padě zla). }\end{array}$ \\
\hline
\end{tabular}

Následující axiomy popisují tzv. moment dobra, fiktivní kvantitativní veličinu vyjadřující množství dobra v každém objektu (37).

\begin{tabular}{|r|l|}
\hline 7. & $\begin{array}{l}\text { Při výpočtu kvantity dobra je v případě stejného trvání momentem } \\
\text { (Moment) dobra jeho intensita, v prŕpadě stejné intensity je jeho } \\
\text { momentem trvání. }\end{array}$ \\
\hline 8. & $\begin{array}{l}\text { Moment dobra v každém objektu je složením proporce trvání a } \\
\text { intensity. }\end{array}$ \\
\hline
\end{tabular}

Další axiom popisuje nutnost odečtení vlivu negativních emocí od celkové sumy dobra (37):

9. Nepř́ijemnost, bolest nebo nebezpečí, která nastanou jednajícímu při získávání nebo podržení dobra, musí být odečteny od sumy dobra (a vice versa $\mathrm{v}$ př́ípadě zla).

Do kalkulace dobra je nutno započítat i pravděpodobnost a nejistotu jeho dosažení (38):

10. Míra nejistoty spojená se získáním či podržením dobra musí být započítána do momentu dobra (a vice versa $\mathrm{v}$ př́padě zla). 
Další axiomy se týkají trvání dobra (38):

\begin{tabular}{|c|c|}
\hline 11. & $\begin{array}{l}\mathrm{V} \text { případě nesmrtelné přirozenosti }{ }^{79} \text { nezáleží na tom, } k d y \text { je dobro } \\
\text { pocit'ováno (ceteris paribus). }\end{array}$ \\
\hline 12. & $\begin{array}{l}\text { Pokud je trvání dobra nekonečné, pak je moment dobra tím větší, čím } \\
\text { dříve dobro nastane. }\end{array}$ \\
\hline 13. & Pro bytosti s konečnou a určitou délkou života. \\
\hline 14. & $\begin{array}{l}\text { Pro bytosti s konečnou a neurčitou délkou života dřivější nastání dobra } \\
\text { zvyšuje jeho moment - na základě nejistoty ohledně délky života. }\end{array}$ \\
\hline
\end{tabular}

Jako vysvětlení k axiomu 12 je jako vysvětlení dodána pozoruhodná věta: „....nebot' konečné přidáno k nekonečnému převyšuje nekonečné samo." (38)

Další axiom se týká zbavení bolesti:

15. Zbavení bolesti je vždy dobrem. Jeho moment je stejným způsobem počítán na základě intenzity, délky trvání a ovlivněn mírou pravděpodobnosti a nejistotou ohledně délky trvání našeho života.

Doposud uvedené axiomy se týkají jak žádostí soukromých, tak žádostí veřejných.

Následujících několik axiomů je věnováno speciálně veřejnému dobru (39):

\begin{tabular}{|r|r|}
\hline 16. & $\begin{array}{l}\text { Naše žádost po veřejném dobru je v proporci k momentu dobra (ceteris } \\
\text { paribus). }\end{array}$ \\
\hline 17. & $\begin{array}{l}\text { Naše veřejná žádost je v proporci k množství lidí, na něž se dobro } \\
\text { může vztahovat, pokud jsou momenty dobra a jiné okolnosti shodné. }\end{array}$ \\
\hline 18. & $\begin{array}{l}\text { Když jsou momenty dobra a množství lidí stejná, pak je naše žádost } \\
\text { v proporci k síle nebo blízkosti (osobních) pout k těmto osobám. }\end{array}$ \\
\hline 19. & $\begin{array}{l}\text { Pokud jsou jiné okolnosti shodné, pak je naše veřejná žádost v proporci } \\
\text { k předpokládané morální výtečnosti osob. }\end{array}$ \\
\hline 20. & $\begin{array}{l}\text { Obecně: síla veřejné žádosti je složena ze samotného množství dobra a } \\
\text { množství, blízkosti a důstojnosti osob. }\end{array}$ \\
\hline
\end{tabular}

${ }^{79}$ Nesmrtelnou přirozeností (immortal Nature) má Hutcheson namysli přirozenost božskou. 


\section{Bibliography}

A. O. Aldridge. A Preview of Hutcheson's Ethics. In: Modern Language Notes, Vol. 61, No. 3 (Mar., 1946), pp. 153-161.

Cicero. De Finibus / On ends. Cambridge: Loeb Classical Library, Harvard university Press. 1989.

Clarke, S. A Demonstration of the Being and Attributes of God And Other Writings, E. Vailati (ed.), Cambridge: Cambridge University Press, 1998.

Fine, R. The history of psychoanalysis. Northvale : Aronson, 1990.

Forsyth, D. R. Group dynamics. Belmont : Wadsworth, 2009.

Frankena, W. Hutchesons Moral Sense Theory. In: Journal of the History of Ideas, Vol. 16, No. 3 (Jun., 1955), str. 356-375.

Hobbes, T. The Elements of Law Natural and Politic. Part I: Human Nature; Part II: De Corpore Politico : with Three Lives. Oxford: Oxford University Press, 2008.

Hobbes. T. Six Lessons to the Professors of the Mathematics. Ep. ded. In: Hobbes, T. The English Works of Thomas Hobbes. Vol. VII. 1839.

Hutcheson, F. Inquiry into the Original of Our Ideas of Beauty. Ed. Wolfgang Leidhold. Indianapolis: Liberty Fund, 2004.

Hutcheson, F. An Inquiry Concerning the Original of Our Ideas of Virtue or Moral Good. In: British Moralists, being Selections from Writers principally of the Eighteenth Century. Edited with an Introduction and analytical Index by L.A. Shelby-Bigge in two volumes. Oxford: Clarendon Press, 1897. Vol. 1.

Korsmeyer, C. W. Relativism and Hutcheson's Aesthetic Theory. In: Journal of the History of Ideas, Vol. 36, No. 2 (Apr. - Jun., 1975), str. 319-330.

Korsmeyer, C. W. The Two Beauties: A Perspective on Hutcheson's Aesthetics. In: The Journal of Aesthetics and Art Criticism, Vol. 38, No. 2 (Winter, 1979), str. 145-151.

Puffendorf, S. On the Duty of Man and Citizen. Printed by John Hayes: Cambridge, 1682 
Shaftesbury. Inquiry Concerning Virtue. In: Shaftesbury, Complete Works, Selected Letters and Posthumous Writings, in English with German Translation. Ed. W. Benda, G. Hemmerich, W. Lottes, U. Schöldbauer, E. Wolff, et alii. Stuttgart: FrommanHolzboog, 1981. Vol. 2.

Sprague, E. Francis Hutcheson and the Moral Sense. In: The Journal of Philosophy, Vol. 51, No. 24, American Philosophical Association, Eastern Division: Papers to be presented at the Fifty-First Annual Meeting, Goucher College, December 28-30, 1954 (Nov. 25, 1954), str. 794-800.

Wollastone, W. The Religion of Nature Delineated. Printed by S. Palmer, 1725. 


\section{E-LOGOS}

ELECTRONIC JOURNAL FOR PHILOSOPHY

Ročník/Year: 2010 (vychází průběžně/ published continuously)

Místo vydání/Place of edition: Praha

ISSN 1211-0442

Vydává/Publisher:

Vysoká škola ekonomická v Praze / University of Economics, Prague

nám. W. Churchilla 4

Czech Republic

13067 Praha 3

IČ: 61384399

Web: http://e-logos.vse.cz

Redakce a technické informace/Editorial staff and technical information:

Miroslav Vacura

vacuram@vse.cz

Redakční rada/Board of editors:

Ladislav Benyovszky (FHS UK Praha, Czech Republic)

Ivan Blecha (FF UP Olomouc, Czech Republic)

Martin Hemelík (VŠP Jihlava, Czech Republic)

Angelo Marocco (Pontifical Athenaeum Regina Apostolorum, Rome, Italy)

Jozef Kelemen (FPF SU Opava, Czech Republic)

Daniel Kroupa (ZU Plzeň, Czech Republic)

Vladimír Kvasnička (FIIT STU Bratislava, Slovak Republic)

Jaroslav Novotný (FHS UK Praha, Czech Republic)

Jakub Novotný (VŠP Jihlava, Czech Republic)

Ján Pavlík (editor-in-chief) (VŠE Praha, Czech Republic)

Karel Pstružina (VŠE Praha, Czech Republic)

Miroslav Vacura (executive editor) (VŠE Praha, Czech Republic) 